\title{
Using of Airborne LiDAR Altimetry and Semi- Automated GIS Tools for Identification and Mapping of Fluvial Terraces in the Augšdaugava Spillway Valley
}

\author{
Juris Soms \\ Dept. of Environmental Science and Chemistry \\ Daugavpils University \\ Daugavpils, Latvia \\ juris.soms@du.lv
}

\author{
Valdis Vorslavs \\ Faculty of Natural Sciences and Mathematics \\ Daugavpils University \\ Daugavpils, Latvia \\ valdis.vorslavs@inbox.lv
}

\begin{abstract}
River terraces are one of the typical and widespread Quaternary fluvial landforms in Latvia. Until recently, distinguishing and mapping of these features have required extensive field surveys. However, the availability of high resolution digital elevation models (DEM) derived from airborne laser altimetry and application of modern geographic information systems (GIS) provides sufficient background to resolve these tasks. In this study, we apply an integrated methodology based on using of remote sensing, i.e. laser scanning or Light Detection and Ranging (LiDAR) data and combining of semi-automated TerEx tools for the detection of fluvial terraces in DEM. The empirical tests performed using the tools in the study area reveal that the application of TerEx gives the reliable results. However, presence of minor landforms which increase the topographical roughness of the surface directly influence the quality of extracted data, thus leading to the necessity of additional manual editing. The obtained data indicate that the terrace sequence in the Augšdaugava spillway valley consists of eight different terrace levels - T1 to T8. Only terraces T1 and $\mathbf{T} 2$ are easily recognizable in the study area, whereas the upper terraces do not have explicit edges.
\end{abstract}

Keywords - Augšdaugava spillway valley, DEM, fluvial terraces, GIS, LiDAR.

\section{INTRODUCTION}

Fluvial terraces are rather common landscape elements of many watercourses located in different regions across the entire planet. These relief features associated with river valleys are typical and widespread Quaternary fluvial landforms in Latvia too [1].
In general, stream terraces can be characterized as geomorphological units of river valleys that developed through the fluvial morphogenesis, i.e. downcutting of water stream into a previously formed floodplain [2]. This process leads to the formation of a distinctive step-like topographic cross profile, where terraces are situated at a higher elevation above the current floodplain. Terraces as features of fluvial origin typically have a relatively flat, sub-horizontal surface, which is separated from the adjacent elements of the valley below or above by a steep slope or scarp [3]. As with other landforms, fluvial terraces are described by the material of which they are formed, in this case - alluvial deposits. Considering the thickness of these deposits, as well as the morphology of terraces, two main types of alluvial terraces can be distinguished - strath or erosional terraces and fill or aggradational terraces [4]. The first ones can be formed in valleys of actively incising rivers and are characterized by thin layers of alluvium covering a bedrock surface. In contrary, fill terraces typically are developed in valleys as a response to stabilization or rise in base level and are characterized by thick deposits of alluvial material covering terrace surfaces [4], [5].

Fluvial terraces are considerably complex since they have been developed in the course of the interplay of many geological processes - incision, accumulation, lateral erosion and mass wasting This fact can be attributed to fluvial terraces in south-eastern Latvia (Fig. 1a), where the terraced Augšdaugava spillway valley (WGS84 5553'44" North and 2652'26" East) (Fig. 1b) represent the evidence of past fluvial activity as driving force of landscape evolution during the transition from glacial to periglacial 
and later to post-glacial conditions in this region [1], [6]. Therefore terraces are substantial 'archives' of paleoenvironmental and geomorphological data, as they could provide key information for a better understanding of the morphogenesis of the spillway valley and to untangle its evolutionary history. In addition, the data obtained from the research of terraces would be also useful to provide the framework for the management and use of natural resources, e.g. identification and assessment of sand and gravel deposits associated with river terraces. Thus it indicates the need for precise identification and mapping of terraces.

However, these geomorphological units as fluvial landforms of complex origin commonly are not well expressed and preserved in the Augšdaugava spillway valley. It is a result of Daugava meandering, topography smoothed by mass wasting and active water erosion processes, making their identification difficult. Until recently, distinguishing and mapping of these features has required extensive field surveys and has been extremely time consuming [7]. However, over the several last years in Latvia, the availability of high resolution DEM derived from airborne laser altimetry and application of modern GIS techniques provides sufficient background to resolve these problems. Hence the main goal of the study presented in this article was to apply an integrated methodology based on using of remote sensing (LiDAR) data and combining of different semi-automated GIS analysis tools for the detection, delineation and mapping of fluvial terraces in DEM.

\section{MATERIALS AND METHODS}

The general aim of this research was to verify a highprecision and high-resolution relief data analysis methodology applying GIS and geospatial analysis for the detection and mapping of fluvial landforms. To reach this aim, a methodology elaborated by Demoulin et al. [8] and further developed by other authors [7]-[9] was applied. In a broader context, this study was carried out to promote and facilitate the understanding of the geological processes and controlling factors involved in the geomorphological evolution of the Augšdaugava spillway valley, terraces of which never before have been studied with this methodology. For this purpose, this study suggests the novelty of using high-resolution (pixel 0,5 m) DEM for processing data on elevation with GIS tools to identify and delineate geomorphological features. Besides, the reliability of the methodology is assessed by comparing and validating the results of GIS analysis with field survey.

In this research, LiDAR data available in the Digital Height Data open data infrastructure [10] of the Latvian Geospatial Information Agency (LGIA) was used to generate a high resolution DEM. In the Augšdaugava spillway valley, the airborne laser scanning coverage provided by LGIA consists of 317 data folders in *.LAS format, each one of $1 \mathrm{~km}^{2}$ extent.

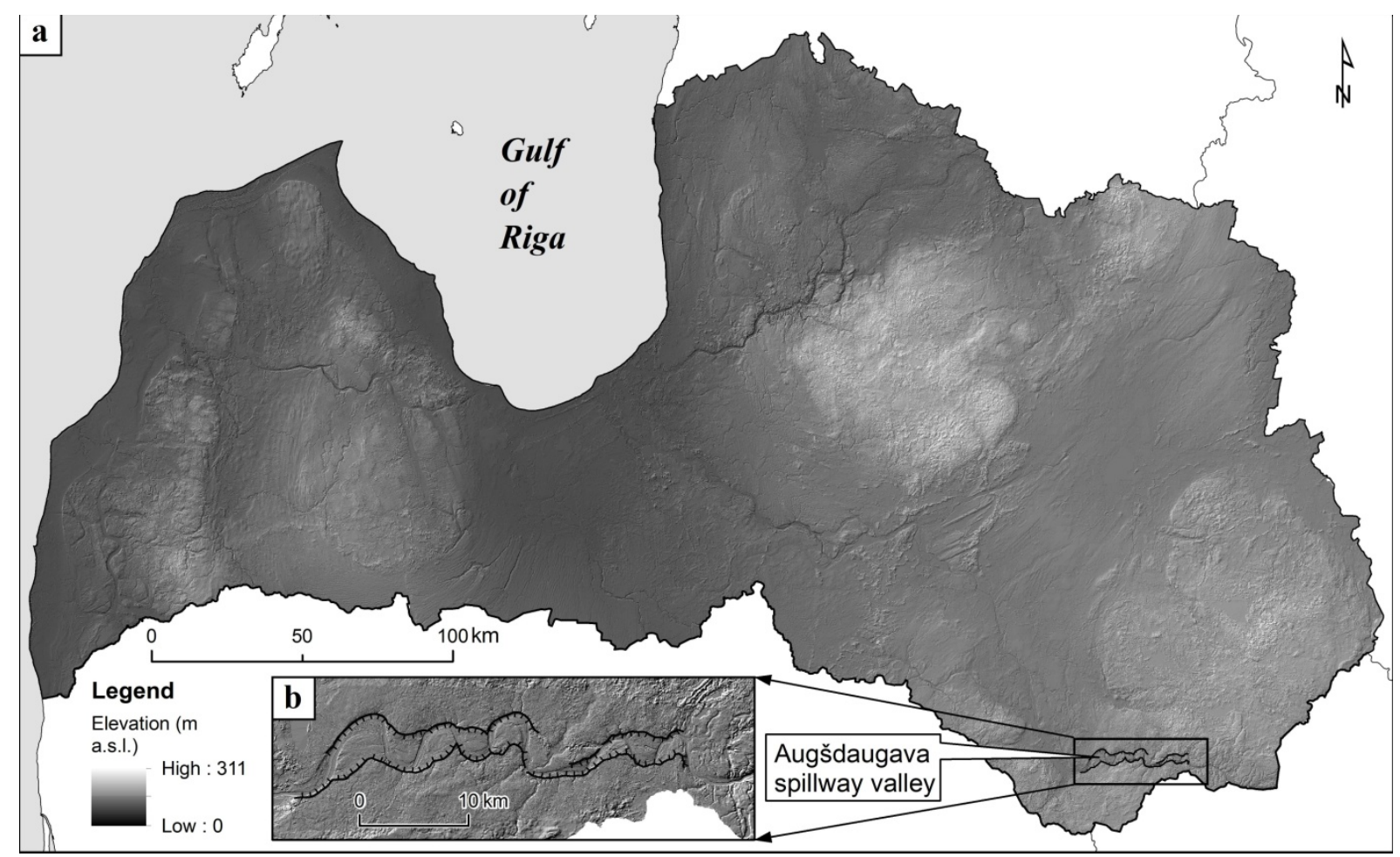

Fig. 1. Location of study area - the Augšdaugava spillway valley in Latvia (A), and relief of the study area and adjacent territories (B) by a shaded DEM in the background. 
The data density of points characterizing the Earth's topographic surface is not less than $4 \mathrm{p} / \mathrm{m}^{2}$ in open areas, and in areas under forest vegetation - not less than 1.5 $\mathrm{p} / \mathrm{m}^{2}$. LiDAR data is linked to the LKS-92 TM coordinate system and LAS-2000.5 for the Latvian standard altitude system. The vertical accuracy of data is up to $0.12 \mathrm{~m}(2 \sigma$ with 95\% confidence level) against the State Geodetic Network, the horizontal accuracy of data is up to $0.36 \mathrm{~m}$ ( $2 \sigma$ with 95\% confidence level) against the State Geodetic Network.

For optimization of DEM constructing process, firstly all 317 LiDAR archives of the *.LAS data points have been merged into *.LAS dataset covering the whole spillway valley. Then LiDAR point cloud was filtered with ArcGIS 10.8.1 software by classification code 'ground' and using the automated tool [11], thus extracting from *.LAS dataset only points representing the bare earth and excluding points other than relief surface. Subsequently, ESRI regular grid raster format DEM with spatial resolution $0.5 \mathrm{~m}$ was created from pre-processed data by ArcGIS tool 'LAS Dataset to Raster' following the standard procedure of the Inverse-Distance Weighting (IDW) interpolation [12]. The IDW is a deterministic method of georeferenced point data interpolation and it is one of the most popular methods adopted in geosciences [13]. The obtained regular grid raster file additionally was processed with the Hydrology Fill tool to get a smoothed DEM with filled sinks and corrected pixels of elevation errors. Vectorised Daugava channel shapefile, river tributaries shapefiles and other additional geospatial data were also prepared for further analysis.

After the construction of DEM, the TerEx toolbox [7] integrated into the ArcGIS environment was used for extraction and delineation of terrace surfaces. Considering physical attributes of real terraces and floodplains, several adjustable parameters have to be set as rules for extraction of terraces in TerEx toolbox: (i) local difference in relief of the flattened surface of terrace cannot exceed a userdefined value (unit - m) within a user-defined area of moving window (unit $-\mathrm{m}^{2}$ ); (ii) the user-defined minimum area of the potential terrace surface (unit $-\mathrm{m}^{2}$ ); (iii) the user-defined width (unit - m) of the spillway valley within which the potential surface of the terrace must be located; and (iv) smoothing parameter (unitless). Following these rules, the semi-automated GIS tools of TerEx perform the identification and delineation of fluvial terraces in two steps. In the first step, the TerEx analyzes DEM and successively performs the following operations: (i) selecting raster cells from DEM which correspond to surfaces of potential terraces; (ii) removing non-selected raster cells that are not surfaces of terraces; (iii) generalizing the shape of the selected surfaces; and (iv) finally producing a shapefile consisting of potential fluvial terrace surfaces. At the end of the first step, the preliminary delineated terraces surfaces should be edited by a user, because these fluvial landforms may be inappropriately identified in cases if the scarp between adjacent flattened surfaces is gentle or modified by erosion, or if the terrace is dissected by gullies or roads, or by other minor landforms.

In the second step, the TerEx uses the Daugava river channel centreline shapefile and splits the stream at a specified interval $(100 \mathrm{~m})$ into equal sections. Then the average elevation of each stream section is automatically extracted from the DEM. After that, the attribute table of terraces is joined with the stream section attribute table, and the average elevation of the terrace surface is calculated. Hence after applying DEM analysis by TerEx tool, a shapefile showing the distribution of terraces and containing data on elevation of terraces is obtained. However, presence of minor landforms which increase the topographical roughness of the surface, e.g. gullies or glaciokarst kettles directly influence the quality of extracted data, thus leading to the necessity of additional manual editing.

In order to provide visual identification of other geomorphological features associated with the surfaces of fluvial terraces, e.g. landforms of aeolian origin, as well as for precise delineation of fluvial relief elements like foothills and edges of terraces, hill-shaded relief model was derived from DEM, and slope and profile curvature GIS tools were applied. In the process of visual interpretation, combining different raster layers, landforms or their elements were manually digitised as polygon or polyline features. Overlaying fluvial terrace surface shapefiles with the latter ones digital geomorphological map of the Augšdaugava spillway valley was developed. After the completion of GIS works, the reliability of the obtained data on the location of fluvial terraces and their elements was assessed during field geomorphological reconnaissance supported by GPS survey. During field expeditions also geological survey was carried out and the spatial distribution of terraces forming Quaternary sediment cover was ascertained. For this purpose mainly conventional geologic survey georeferenced by GPS, i.e., hand-dug pits and near-surface augering by AMS Mud Auger or Eijkelkamp equipment were used to investigate the lithofacies of sediments, as well as their spatial distribution. These data were compiled with the geomorphological map of terraces identified from DEM; hence the detailed framework for further studies was established.

\section{RESULTS AND DISCUSSION}

Fluvial terraces represent evidence of incision by fluvial activity in the Augšdaugava spillway valley, and as it was mentioned before, are substantial 'geo-archives' of paleoenvironmental and geomorphological data. Therefore it is necessary to identify precisely the number, elevation and distribution of terraces along the present-day profile of the river within the Augšdaugava spillway valley, which is one of the largest and at the same time oldest of such landforms in Latvia [14]. Notwithstanding that studies on the development and geomorphology of the terraced spillway valley have been carried out in Latvia since the 1930s [15], these issues are still under debate. According to different scientific publications, the number 
of terraces distinguished by independent authors in the spillway valley varies. Thus, Majore [16] described the sequence of five terraces, whereas Eberhards [1], [14] identified eight terraces. Furthermore, G. Eberhards (ibid.) identified the upper terraces T7 and T8 only as fragments in some parts of the spillway valley. Despite the differences in the number of distinguished terraces, there is a consensus among scientists that the development of these fluvial landforms has started during the retreat of glacier of the last Weichselian glaciation [6].

In order to obtain scientifically reliable data on the distribution of flattened surfaces of terraces in the study area as well as on their elevation, series of geospatial data in shapefile format was acquired during the semiautomated extraction from DEM by TerEx tools. In the course of performed many empirical tests and comparison of shapefile series with terrace surfaces visually distinguishable in the DEM, authors found that the TerEx tools provide the best results when adjustable parameters - specified change in elevation, minimum terrace area, focal window and smoothing parameter were set as $0.5 \mathrm{~m}$; $10,000 \mathrm{~m}^{2} ; 3$ pixels and 45 units, respectively. To ensure that the surfaces of terraces extracted from DEM are accurate, field geomorphological observations were carried out in situ along the transect lines from the spillway valley margin to the top of the meander bend.

After applying the GIS based semi-automated methodology to extract potential fluvial terraces in the Augšdaugava spillway valley from airborne LiDARderived high resolution DEM, a detailed map of terrace surfaces and their elevation is obtained in this research, finally answering the question about the exact number of terraces in sequence typical for the study area. To be specific, DEM analysis allowed to identify the terrace sequence in the Augšdaugava spillway valley consisting of eight different terrace levels - T1 to T8 where the number indicates terrace elevation in the sequence from the lowest to the highest, respectively (Fig. 2a).

From the applied methodology, authors were able to delineate surfaces of fluvial terraces in those parts of the study area, where in the course of previous research [14] terraces were interpreted incorrectly or even not identified at all. The results of DEM analysis indicate, that fluvial terrace sequences in the Augšdaugava spillway valley are located asymmetrically, i.e. making step-like landscape on the inside of meander bends, whilst on the outside of bends only T1 or T2 usually are presented and the spillway valley margin is delimited by steep slopes (Fig. 2b). The terraces (except terrace T1) which are found at certain elevations typically are not matched with ones at the same elevations across the spillway valley, indicating that these fluvial landforms identified in the study area refer to unpaired terraces.

Such geomorphological finding on the asymmetrical distribution of unpaired terraces indicates that the River Daugava during its paleogeographic development has phases of down cutting (due to change of base-level) alternate with phases of stabilization and accumulation.
Simultaneously lateral migration and meandering of the river channel took place, thus creating step-like terrace sequences inside of meander bends and eroding the terrace surfaces adjoining to the outside of bends. This is consistent with an erosional scenario of the spillway valley development and geomorphology [14].

The GIS analysis of individual elements of the terrace sequence in the Augšdaugava spillway valley reveals that only terrace $\mathrm{T} 1$ can only be unambiguously identified along the present-day profile of the river and throughout the entire spillway valley. The terrace T2 also is easily recognizable, however, it encounters only in shorter stretches in comparison to T1. Both T1 and T2 terraces have pronounced edge between their flattened tread and steep slope, and their both are bounded by the riser of the lowermost surface of floodplain or terrace. Contrary to the rest of the terraces in the sequence, the surface of $\mathrm{T} 1$ usually matches with one at the same elevation across the river. Hence T1 refers to paired terraces.

The results of the geological survey indicate that $\mathrm{T} 1$, which also is the youngest terrace in this stretch of the Daugava, is an aggradational or fill terrace, consisting of typical alluvial sand deposits. On the surface of terrace T1 in several hand-dug pits and drillings, the buried soils with small pieces of charcoal were found at a depth from $0.9 \mathrm{~m}$ to $0.3 \mathrm{~m}$. The radiocarbon dating of the charcoal performed in other research [17] shows that the age of this material is $255 \pm 30$ cal yr BP or AD 1620-1675 (sample No. Poz76256, Poznan Radiocarbon Laboratory). Despite our preliminary assumptions that dates would indicate the beginning of settlement history and slash-and-burn agriculture activities related to the Iron Age in this area or, the development of terrace T1 in the Atlantic period, the results display that deposited material is younger. The texture and granulometric properties of the layer covering charcoal point to an aeolian origin of sand. This fact in combination with results of the ${ }^{14} \mathrm{C}$ dating in turn indicates that in Medieval Times, i.e. during the Little Ice age (as indicate the dates), high-magnitude wind-driven geomorphic processes took place in the Augšdaugava spillway valley, leading to intensive deposition of aeolian sediments and burring of soils and organic material. 
Environment. Technology. Resources. Rezekne, Latvia Proceedings of the $13^{\text {th }}$ International Scientific and Practical Conference. Volume 1, 230-236
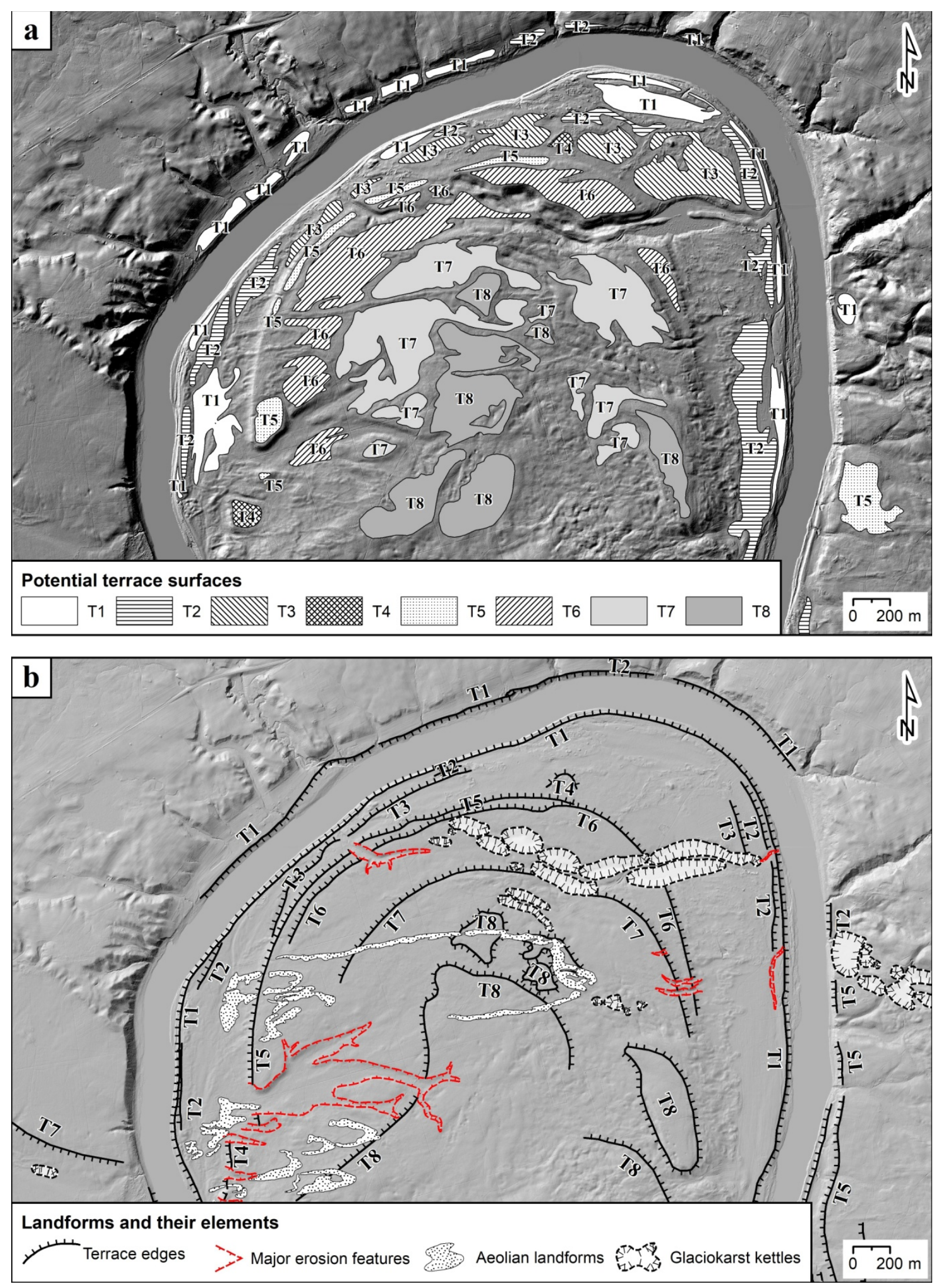

Fig. 2. Distribution of fluvial terraces in the Augšdaugava spillway valley - an example from the Daugavsargu meander: (a) eight levels of potential terrace surfaces extracted and mapped by TerEx tools - map over LiDAR data based shaded DEM; (b) geomorphological map with identified landforms. Terrace edges delineated only for those segments which have explicit break detectable in DEM or by the field survey. 
Hence the findings of this research will stimulate to carry out additional and new studies, because geomorphic events of the Little Ice age remain poorly documented in this part of Latvia, thus the extent to which environmental conditions and controlling factors of processes during this time are currently studied is insufficient.

The evidence of presumable past aeolian activity is represented also by linear or parabolic dunes the length of which in some bends exceeds $0.5 \mathrm{~km}$ (Fig. 2b). These linear landforms have an orientation from $\mathrm{W}$ to $\mathrm{E}$, with elongated crests sub-parallel to the margins of the spillway valley. Such orientation of dune linear axis possible can be explained by the formation of tunnel effect during air mass transfer through the depression of the spillway valley by prevailing westward winds. The groups of dunes stretch across the surface of terraces situated at different elevations and this fact directly indicates the later origin of aeolian features in comparison to fluvial terraces. The finding of inland dunes in the study area is the geomorphological novelty directly related to capabilities of identification small relief features in the high resolution DEM.

Summarizing the results for terraces $\mathrm{T} 2$ to $\mathrm{T} 8$ it is necessary to note, that, unlike $\mathrm{T} 1$, other terraces situated at higher levels do not form a continuous spectrum along the longitudinal profile of the river and are encountered only in some stretches of the spillway valley. The treads of these terraces occur fragmentary as flat-topped erosional remnants of different size (Fig. 2b), and the edges of these terraces are smoothed or modified by exogenic geological processes. Particularly dissected and fragmented are terraces T3 and T4, which throughout the entire studied valley can be identified neither in DEM nor in nature as typical fluvial terraces with flattened surface and topographically well-expressed edge.

The GIS analysis of DEM and subsequent geomorphological field survey also allowed to identify many glaciokarst kettles on the surfaces of terraces T3 T8 (Fig. 2b). These kettles occur as slightly elongated, semi-circular in planar view closed depressions, which form groups over inside of meander bends in several meanders.

Finally, the results of DEM analysis, geomorphological reconnaissance and geological field survey indicate that morphogenesis of the uppermost terraces T7 and T8 is still an open question. The edges of these terraces are very smoothed, but surfaces are complicated by dispersed microforms like old gullies (presumably of the Late Pleistocene time), other erosional features and depressions of different size and shape. The terraces constitute of poorly-sorted deposits with texture and granulometric properties characteristic for glacioaquatic sediments. Moreover, the surfaces of T7 and T8 are sub-horizontal or even incline slightly to the east, i.e. in the direction of the former Polotsk ice-dammed lake. The previous assertion [1], [14] has specified that the terraces T7 and T8 were erosional, formed by streams of glacial meltwater flowing westward from Lake Polotsk into the Nīcgale ice-dammed lake at the initial phase of development of the Augšdaugava spillway valley. Eberhards [14] attempted to explain the upstream inclination of the levels of both above mentioned terrace treads, opposite to the direction of paleo-stream flow, in terms of glacial isostatic adjustment. Without completely rejecting the idea of changing the terrace treads inclination caused by Late Glacial glacio-isostatic uplift, the results of recent research lead to a different assumption and reveal that terraces T7 and T8 are not fluvial erosional terraces but kame terraces. However, to verify this assumption, it is necessary to perform optically stimulated luminescence (OSL) dating of T7 and T8 forming sediments. Hence it's obvious the need for more detailed and complex further studies.

\section{CONCLUSIONS}

The main goal of the applied methodology to detect and delineate potential fluvial terrace areas from remote sensing (LiDAR) data using semi-automated GIS analysis tools has been achieved. The high resolution digital elevation models derived from airborne laser altimetry can be used GIS environment to extract fluvial landforms, their elements and minor geomorphological features in river valleys, where an extensive amount of time and workload would spend to obtain the same data by conventional field survey and geomorphological reconnaissance. The main advantages of using semi-automated GIS tools are avoiding the subjectivity related to the manual identification of the landforms, and rapidity of data processing and obtaining of results, thus allowing to process and elaborate digital geomorphological maps of relatively large areas readily and consistently. Additionally, the advantage also is the analysis and classification of the relief at finer scales due to higher resolution elevation data. Hence the obtained results provide much more information than those previously obtained from analysis of topographic maps and manual digitizing of contour lines, particularly in terms of interpretation of local morphology of fluvial terraces. However, the required input parameters for TerEx tools have to be adjusted empirically to optimize automated extraction and delineation of fluvial terraces, and subsequent ground-truthing should be performed to validate the results of GIS analysis.

New and scientifically more reliable data have been obtained on the exact number of terraces in sequence typical for the Augšdaugava spillway valley, consisting of eight different terrace levels - T1 to T8. In the Augšdaugava spillway valley, however, it is not common to observe well-preserved terraces at levels higher than T2. Furthermore, morphogenesis of the uppermost terraces T7 and T8 is an issue which is still under debate.

Also, the results of the geological field survey lead to the conclusion that during the Little Ice age, highmagnitude wind-driven geomorphic processes took place in the study area. Hence the findings of this research will stimulate to carry out more detailed and complex further studies in the Augšdaugava spillway valley. 


\section{REFERENCES}

[1] G. Eberhards, Upju ieleju veidošanās un mūsdienu gultnes procesi Dienvidaustrumu Baltijā (Development of river valleys and channel processes in Southeatern Baltic), in Latvian. Rīga: Latvijas Universitāte, 2013, pp. 211.

[2] R. Charlton, Fundamentals of fluvial geomorphology, London: Routledge, 2009, pp. 163.

[3] M. A. Summerfield, Global geomorphology, Harlow: Longman, 1999, pp. 224-225.

[4] F.J. Pazzaglia, "Fluvial terraces (chapt. 9.22.)," In Treatise on Geomorphology, F.S. John, Ed. San Diego: Academic Press, 2013, pp. 379-412.

[5] G.S. Hancock, R.S. Anderson, "Numerical modeling of fluvial strath terrace formation in response to oscillating climate," GSA Bulletin, vol. 114 (9), pp. 1131-1142, Sept. 2002. https://doi.org/10.1130/00167606(2002)114<1131:NMOFST>2.0.CO;2

[6] V. Zelčs, A. Markots, M. Nartišs, T. Saks, "Pleistocene Glaciations in Latvia,” In Developments in Quaternary Science, vol. 15, J. Ehlers, P.L. Gibbard, P.D. Hughes (Eds.). Amsterdam: Elsevier, 2011, pp. 221-229.

[7] J. C. Stout, P. Belmont, "TerEx Toolbox for semi-automated selection of fluvial terrace and floodplain features from LiDAR,” Earth Surface Processes and Landforms, vol. 39 (50), pp. 569-580, Apr. 2014. https://doi.org/10.1002/esp.3464

[8] A. Demoulin, B. Bovy, G. Rixhon, Y. Cornet, “An automated method to extract fluvial terraces from digital elevation models: The Vesdre valley, a case study in eastern Belgium," Geomorphology, vol. 91 (1-2), pp. 51-64, Oct. 2007. https://doi.org/10.1016/j.geomorph.2007.01.020

[9] M. del Val, E. Iriarte, M. Arriolabengoa, A. Aranburu, “An automated method to extract fluvial terraces from LIDAR based high resolution Digital Elevation Models: The Oiartzun valley, a case study in the Cantabrian Margin,” Quaternary International, vol. 364, pp. 35-43, Apr. 2015. https://doi.org/10.1016/j.quaint.2014.10.030
[10] Latvian Geospatial Information Agency, "Digital Height Model Basic data,” LGIA, Open data, 2021. [Online]. Available: https://www.lgia.gov.lv/lv/Digit\%C4\%81lais\%20virsmas\%20mod elis [Accesed: Jan. 17, 2021]

[11] G. Sithole, G. Vosselman, "Experimental comparison of filter algorithms for bare-Earth extraction from airborne laser scanning point clouds,” ISPRS J. Photogramm. Remote Sens., vol. 59 (1-2), pp. 85-101, Aug. 2004. https://doi.org/10.1016/j.isprsjprs.2004.05.004

[12] N. Polat, M. Uysal, A. S. Toprak, “An investigation of DEM generation process based on LiDAR data filtering, decimation, and interpolation methods for an urban area,” Measurement, vol. 75, pp. 50-56, Nov. 2015. http://dx.doi.org/10.1016/j.measurement.2015.08.008

[13] G.Y. Lu, D.W. Wong, “An adaptive inverse-distance weighting spatial interpolation technique,” Comput. Geosci., vol. 34, pp. 1044-1055, $\quad$ Sept. 2008. https://doi.org/10.1016/j.cageo.2007.07.010

[14] G. Eberhards, Stroyeniye i razvitiye dolin basseyna reki Daugava (Structure and development of valleys of the Daugava river catchment), in Russian. Rīga: Zinātne, 1972, pp.131.

[15] I. Sleinis, K. Ašmanis, N. Delle, J. Silinšs, V. Lamsters, Daugava (The River Daugava), in Latvian. Rīga: Valters un Rapa, 1933, pp. 107.

[16] M. Majore, Daugavas ielejas attīstiba (Development of the Daugava river valley), in Latvian. Rīga: Latvijas valsts izdevniecība, 1962, pp. 77.

[17] E. Muižniece, J. Soms, “A geomorphological approach for enhancing environmental management and conservation of landforms as protected nature objects in the Upper Daugava spillway valley," In Proceedings of the $10^{\text {th }}$ International Scientific and Practical Conference "Environment. Technology. Resources". Rēzekne, Latvia, 20 - 22 June, 2015. vol.2., pp.225-231. http://dx.doi.org/10.17770/etr2015vol2.252 